\title{
Pengaruh Budaya Belajar terhadap Self-Efficacy Siswa Cerdas Istimewa di Sekolah Menengah Atas
}

\author{
Ananda Aprilia ${ }^{1}$, Siti Masyithoh ${ }^{2}$, Mu'arif SAM ${ }^{3}$ \\ Fakultas IImu Tarbiyah dan Keguruan, UIN Syarif Hidayatullah Jakarta ${ }^{1,2,3}$ \\ Email: anandaapriliaa@gmail.com, siti.masyithoh@uinjkt.ac.id, muarif@uinjkt.ac.id
}

Riwayat artikel: submit: 17 September 2021; revisi: 27 September 2021, diterima: 30 September 2021

\begin{abstract}
ABSTRAK
Penelitian ini bertujuan untuk mengumpulkan data empiris tentang pengaruh budaya belajar terhadap self-efficacy siswa cerdas istimewa di SMAN 78 Jakarta. Penelitian ini menggunakan metode kuantitatif dengan analisis regresi linear sederhana dan pengambilan sampel berdasarkan teknik simple random sampling dengan penentuan jumlah sampel yang dikembangkan oleh Isaac dan Michael. Data dikumpulkan menggunakan angket, wawancara, dan studi dokumentasi. Berdasarkan pengolahan data SPSS Ver.22, hasil pengujian korelasi (uji-r) menunjukkan rhitung bernilai positif sebesar 0,829 > rtabel sebesar 0,304 dengan signifikansi sebesar $0,000<0,05$, maka terdapat hubungan yang signifikan antara budaya belajar terhadap self-efficacy siswa cerdas istimewa dalam tingkatan sangat kuat dan searah. Hasil perhitungan regresi linear sederhana menghasilkan koefisien regresi sebesar 0,845 yang diinterpretasikan budaya belajar berpengaruh positif terhadap self-efficacy siswa cerdas istimewa. Pada perhitungan koefisien determinasi diketahui pengaruh budaya belajar terhadap self-efficacy siswa cerdas istimewa sebesar $68,6 \%$, sementara sisanya $31,4 \%$ dipengaruhi oleh faktor lain yang tidak diteliti. Dapat disimpulkan budaya belajar berpengaruh positif sebesar $68,6 \%$ terhadap self-efficacy siswa cerdas istimewa. Semakin baik budaya belajar siswa cerdas istimewa maka akan semakin tinggi self-efficacynya.
\end{abstract}

Kata kunci: Budaya Belajar, Self-Efficacy, Siswa Cerdas Istimewa.

\section{ABSTRACT}

The study aims to collect empirical data on the effect of learning culture on the self-efficacy of special intelligent students at SMAN 78 Jakarta. This study uses a quantitative method with simple linear regression analysis and sampling based on simple random sampling technique by determining the number of samples developed by Isaac and Michael. Data were collected using questionnaires, interviews, and documentation studies. Based on SPSS Ver.22 data processing, the results of the correlation test (r-test) show that rcount has a positive value of $0.829>$ rtable of 0.304 with a significance of $0.000<0.05$, then there is a significant correlation between learning culture and selfefficacy of special intelligent students in a very strong and unidirectional level. The results of simple linear regression calculations produce a regression coefficient of 0.845 which is interpreted that learning culture has a positive effect on the self-efficacy of special intelligent students. In the calculation of the coefficient of determination, it's known that the effect of learning culture on the selfefficacy of special intelligent students is $68.6 \%$, while the remaining $31.4 \%$ is influenced by other factors not examined. It can be concluded learning culture has a positive effect of $68.6 \%$ on the self-efficacy of special intelligent students. The better learning culture of special intelligent students, the higher their self-efficacy.

Keywords: Learning Culture, Self-Efficacy, Special Intelligent Students. 
Aprilia. A. (2021). Pengaruh Budaya Belajar terhadap Self-Efficacy Siswa Cerdas Istimewa di Sekolah Menengah Atas. Edudikara: Jurnal Pendidikan dan Pembelajaran, 6(3), 244-254.

\section{PENDAHULUAN}

Setiap warga negara memiliki hak yang sama dalam kehidupan termasuk memperoleh pelayanan pendidikan. Hak untuk dapat memperoleh pendidikan melekat pada semua orang tanpa kecuali, termasuk anak yang memiliki kebutuhan-kebutuhan khusus. Anak yang memiliki kekhususan berhak mendapat pelayanan pendidikan sesuai kebutuhannya namun tetap hidup bersama dalam situasi sosial yang alamiah. Pemerintah telah berupaya memfasilitasi regulasi pendidikan guna memberikan pelayanan kepada seluruh siswa dengan dikeluarkannya UU No. 20 tahun 2003 tentang Sistem Pendidikan Nasional yaitu: Pasal 5 ayat (4), "Warga negara yang memiliki potensi kecerdasan dan bakat istimewa berhak memperoleh pendidikan khusus." Dengan demikian, pemerintah mengamanatkan tentang perlunya memberikan pendidikan khusus bagi siswa yang memiliki potensi kecerdasan istimewa. Hal ini dilakukan agar potensi yang dimiliki oleh siswa dapat berkembang secara optimal sehingga mereka dapat tumbuh menjadi manusia yang beriman, bertaqwa kepada Tuhan yang Maha Esa, berakhlak mulia, berilmu, cakap, kreatif, dan mandiri.

Selain itu, pemerintah juga telah berupaya untuk memberikan pelayanan pendidikan bagi siswa yang memiliki potensi kecerdasan istimewa. Program layanan bagi siswa cerdas istimewa yang lebih dulu berkembang adalah Grade-Based-Acceleration di mana siswa dapat menyelesaikan masa belajar lebih cepat daripada teman seusianya (Deden Saipul Hidayat dan Wawan Gunawan' 2013). Saat ini layanan pendidikan khusus bagi siswa cerdas istimewa dapat dilaksanakan dalam program percepatan dengan diversifikasi, di antaranya: pendidikan khusus atau sekolah khusus siswa cerdas istimewa, kelas khusus misalnya dalam bentuk kelas akselerasi, atau pembelajaran khusus misalnya melalui sistem kredit dengan beban belajar (sks) lebih banyak. Pada tahun 2015, layanan pendidikan khusus dalam bentuk kelas akselerasi sudah dihapuskan oleh Kemendikbud, sebagai gantinya diterapkanlah program Sistem Kredit Semester (SKS) untuk memfasilitasi kecepatan belajar dan kecerdasan siswa yang berbedabeda.

Pada tahun 2007 dibentuk Asosiasi Penyelenggara, Pengembang, dan Pendukung Pendidikan Khusus Untuk Siswa Cerdas/Berbakat Istimewa (Asosiasi $\mathrm{Cl}+\mathrm{BI}$ ) yang melibatkan unsur perguruan tinggi, sekolah-sekolah aksel, kelompok masyarakat (lembaga seni, olahraga, program keberbakatan), serta perwakilan dari Dinas Pendidikan dan Direktorat PSLB. Asosiasi $\mathrm{Cl}+\mathrm{BI}$ mewadahi peran serta masyarakat dalam rangka peningkatan mutu secara berkelanjutan dan efektivitas penyelenggaraan pendidikan khusus bagi siswa yang memiliki potensi kecerdasan dan/atau bakat istimewa. Terdapat juga beberapa komunitas yang dibentuk orang tua yang memiliki anak gifted, yakni Parents Support Group for Gifted Children Jogja (PSGGC), Center for Gifted and Talented Indonesia (CGTI), dan lain sebagainya. Dengan demikian, seluruh pihak baik pemerintah, sekolah, orang tua, dan masyarakat telah berupaya memberikan layanan pendidikan yang bermutu bagi siswa cerdas istimewa.

Dalam dunia pendidikan, Renzulli merupakan tokoh yang terkenal dengan teorinya yang mendasari pemahaman tentang kecerdasan istimewa. Menurutnya, siswa cerdas istimewa adalah siswa yang memiliki kemampuan intelegensi di atas rata-rata, memiliki kreativitas serta komitmen terhadap tugas yang juga tinggi (Nanang Rosadi dan Iwan Wahyu Widayat, 2013). Pemahaman Renzulli ini dikenal dengan nama The Three Ring of Renzulli atau Tiga Cincin Renzulli. Penambahan kreatif dan komitmen terhadap tugas dalam definisi cerdas istimewa menunjukkan adanya performansi lain di luar pengukuran intelegensi secara tradisional. Siswa yang mendapat kategori cerdas istimewa karena skor IQ tinggi dapat berhenti menjadi siswa cerdas istimewa; sebaliknya siswa yang bukan cerdas istimewa dapat menjadi cerdas istimewa karena kreativitas dan komitmennya terhadap tugas (Rini Sugiarti, 2019).

Siswa cerdas istimewa merupakan sumber daya manusia yang unggul dan diharapkan memberikan kontribusi yang besar dalam kehidupan masyarakat, termasuk berprestasi dalam bidang akademik. Dengan adanya kecerdasan yang luar biasa ini, seharusnya siswa cerdas 
Aprilia. A. (2021). Pengaruh Budaya Belajar terhadap Self-Efficacy Siswa Cerdas Istimewa di Sekolah Menengah Atas. Edudikara: Jurnal Pendidikan dan Pembelajaran, 6(3), 244-254.

istimewa memiliki self-efficacy yang tinggi dan prestasi belajar yang tinggi pula, namun sering dijumpai mereka yang justru tidak percaya diri dengan kemampuannya sehingga tidak dapat memperlihatkan prestasi luar biasanya.

Bandura adalah tokoh yang memperkenalkan istilah self-efficacy atau efikasi diri. Konsep ini banyak diadopsi untuk berbagai keperluan, terutama dalam hal belajar. Bandura menggunakan istilah self-efficacy mengacu pada keyakinan atau kepercayaan (beliefs) tentang kemampuan seseorang (Abd. Mukhid, 2009). Self-efficacy merupakan penilaian atau keyakinan individu terhadap kemampuan yang dimiliki. Self-efficacy dapat membawa perilaku yang berbeda antara individu meskipun mereka memiliki kemampuan yang sama, karena selfefficacy memengaruhi pilihan, tujuan, pengatasan masalah, dan kegigihan dalam berusaha. Oleh karena itu, siswa cerdas istimewa dengan tingkat kemampuan yang sama memungkinkan untuk mendapat prestasi belajar yang berbeda karena level self-efficacy yang dimilikinya.

Hasil penelitian Febriana dan Desi dengan judul Hubungan Self Efficacy dengan Prestasi Belajar Siswa Akselerasi (2013) menunjukkan pada kelas percepatan belajar masih ada siswa yang belum bisa menunjukkan prestasi belajar secara optimal. Prestasi belajar yang kurang optimal ini dikarenakan kurangnya self-efficacy siswa terhadap kemampuan yang mereka miliki. Penelitian Silvia Wulandari dan Mira Aliza berjudul Efikasi Diri dan Stress Akademik pada Siswa SMA Program Akselerasi (2014) juga mengungkapkan bahwa siswa dengan kecerdasan tinggi mempunyai kemudahan untuk mengalami stress akademik, mudah mengalami frustasi, merasa tegang, bahkan hilang keyakinan dirinya untuk menjalani tuntutan hidup yang dihadapinya, terutama dalam hal persaingan akademik. Hasil penelitian tersebut menunjukkan self-efficacy berpengaruh $59 \%$ terhadap stress akademik pada siswa cerdas istimewa.

Lebih lanjut disebutkan terdapat beberapa masalah internal yang dimiliki oleh siswa cerdas istimewa, antara lain; ragu terhadap diri sendiri, citra diri yang buruk, kecemasan terhadap diri yang berlebihan, kemampuan berpikir kritis dapat mengarah ke sikap meragukan (skeptis) terhadap diri sendiri maupun orang lain, kemampuan kreatif dan minat untuk melakukan hal-hal baru bisa menyebabkan mereka tidak menyukai atau lekas bosan terhadap tugas-tugas tertentu, sikap acuh tak acuh dan malas dapat timbul karena pengajaran yang diberikan di sekolah kurang mengundang tantangan baginya (Deden Saipul Hidayat dan Wawan Gunawan, 2013). Siswa cerdas istimewa dengan prestasi rendah juga memiliki karakteristik kurangnya motivasi/tujuan, rendahnya rasa kepercayaan diri, perasaan rendah diri, dan ketidakmampuan untuk bertahan. Prestasi belajar yang rendah ini dikarenakan kurangnya self-efficacy siswa terhadap kemampuan yang dimiliki.

Stanhope \& Bell (Nur Eva dan Moh. Bisri, 2018) menjelaskan siswa cerdas istimewa yang menjadi underachiever dapat disebabkan pula karena pola perilaku orang tua yang overprotective ataupun terlalu menekan anak untuk menunjukkan prestasi. Terkadang terdapat materi yang tidak dipahami siswa karena guru terlalu cepat menerangkan. Guru dan orang tua juga kesulitan dalam membantu siswa cerdas istimewa mengembangkan kemampuan sosialisasi. Selain itu, adanya pengaruh teman sebaya menghalangi prestasi belajar mereka, seperti mengajak bermain dan penerimaan yang kurang kepada anak yang serius belajar.

Selama ini siswa cerdas istimewa dianggap sebagai siswa yang pandai dan dapat menghadapi berbagai situasi yang sulit karena memiliki kecerdasan yang tinggi dibandingkan siswa biasa, bahkan mereka dianggap sebagai siswa yang tidak memiliki masalah. Namun sejumlah fakta di atas menunjukkan bahwa siswa cerdas istimewa juga memiliki masalah yang sama dengan siswa biasa, bahkan cenderung lebih kompleks, baik dari segi sosial, emosional, dan kepribadiannya. Adanya keraguan terhadap diri dan kemampuan yang dimiliki, rendahnya rasa kepercayaan diri, citra diri yang buruk, kecemasan yang berlebihan, komitmen yang lemah terhadap tugas, ketidakmampuan untuk bertahan, dan tidak optimalnya prestasi belajar yang diraih merupakan indikasi rendahnya self-efficacy yang dimiliki siswa cerdas istimewa. 
Aprilia. A. (2021). Pengaruh Budaya Belajar terhadap Self-Efficacy Siswa Cerdas Istimewa di Sekolah Menengah Atas. Edudikara: Jurnal Pendidikan dan Pembelajaran, 6(3), 244-254.

Menurut Bandura, self-efficacy pada tiap individu akan berbeda antara satu dengan yang lainnya berdasarkan tiga dimensi, yaitu level, strength, dan generality (M. Ghufron dan Rini Risnawita, 2012). Hal ini didukung oleh pendapat Gist dan Mitchell (M. Ghufron dan Rini Risnawita, 2012) yang mengemukakan self efficacy dapat membawa perilaku yang berbeda di antara individu dengan kemampuan yang sama, karena self efficacy memengaruhi pilihan, tujuan, pengatasan masalah, dan kegigihan dalam berusaha. Oleh sebab itu, self-efficacy yang dimiliki oleh siswa, baik siswa biasa maupun siswa cerdas istimewa tentu akan berbeda. Bahkan self-efficacy antara siswa cerdas istimewa dengan siswa cerdas istimewa lainnya juga akan berbeda, meskipun mereka memiliki kecerdasan atau kemampuan yang sama.

Dalam situasi yang sulit, individu dengan self-efficacy rendah cenderung mudah menyerah dan menganggap dirinya tidak mampu mengerjakan sesuatu yang ada di sekitarnya. Sementara individu dengan self-efficacy tinggi akan berusaha lebih keras untuk mengatasi tantangan yang ada. Bandura (Tim Psychologimania) mengemukakan bahwa salah satu faktor yang mempengaruhi self efficacy adalah faktor budaya. Budaya mempengaruhi self efficacy melalui nilai (values), kepercayaan (beliefs), dan proses pengaturan diri (self-regulatory process) yang berfungsi sebagai sumber penilaian self efficacy dan konsekuensi dari keyakinan akan self efficacy. Budaya yang diperoleh melalui proses pembelajaran oleh seseorang atau sekelompok orang dalam lingkungannya dapat berkembang menjadi budaya belajar.

Tabrani Rusyan (2007) mengemukakan budaya belajar merupakan serangkaian kegiatan dalam melaksanakan tugas belajar yang dilakukan. Siswa menjadikan belajar sebagai kebiasaan, kegemaran, dan kesenangan, sehingga motivasi belajar muncul dari dalam diri yang akhirnya produktivitas belajar meningkat. Berkaitan dengan hal tersebut, budaya belajar ditafsirkan sebagai kebiasaan belajar yang dilakukan individu dalam melaksanakan tugas belajarnya.

Budaya belajar yang diterapkan oleh siswa cerdas istimewa tidak terlepas dari lingkungan belajar yang membentuk mereka, yaitu sekolah. Sekolah yang memiliki budaya organisasi kuat dan didasarkan pada nilai dan norma tertentu akan berpengaruh terhadap budaya belajar peserta didiknya. Oleh karena itu, untuk membangun budaya belajar peserta didik harus diawali dari membangun budaya organisasi (sekolah) yang bersangkutan. Adanya budaya belajar merupakan salah satu upaya meningkatkan kualitas belajar, karena dengan budaya belajar segala kegiatan pembelajaran dan tugas akan teratur dan terarah, sehingga tujuan belajar yang diharapkan dapat tercapai dengan baik.

Tabrani Rusyan (2007) menegaskan budaya belajar merupakan salah satu upaya meningkatkan kualitas belajar, karena dengan budaya belajar segala kegiatan pelajaran dan tugas akan teratur dan terarah sehingga tujuan belajar yang diharapkan akan tercapai dengan baik. Penerapan budaya belajar yang baik, meliputi: budaya kepatuhan, budaya inovatif, budaya profesional, budaya berprestasi, budaya memuaskan, dan budaya integritas. Budaya yang negatif dan salah dalam dunia pendidikan akan berpengaruh terhadap perkembangan dan pertumbuhan anak sehingga dibutuhkan sebuah budaya belajar. Budaya belajar yang terbentuk dalam suatu area belajar yaitu sekolah, nantinya akan mampu mengatur sebuah pola perilaku, pola interaksi, pola pembelajaran bahkan karakter peserta didik sesuai yang diharapkan. Slameto (2018) berpendapat bahwa banyak siswa gagal belajar akibat mereka tidak mempunyai budaya belajar yang baik. Budaya belajar yang kurang baik akan membentuk siswa menjadi pribadi yang malas, bertindak semaunya sendiri, dan tidak teratur.

Di tengah banyaknya sekolah yang belum menerapkan budaya belajar secara baik, ada sekolah yang telah berupaya menerapkan budaya belajar yang baik, yakni SMAN 78 Jakarta. Hal ini dibuktikan dengan banyaknya prestasi akademik maupun non akademik baik di tingkat Nasional dan Internasional yang telah diraih. Sekolah ini juga pernah ditetapkan sebagai sekolah RSBI (Rintisan Sekolah Bertaraf Internasional) pada tahun 2006 meskipun saat ini sudah dihapuskan. SMAN 78 Jakarta merupakan lembaga pendidikan yang mempersiapkan 
Aprilia. A. (2021). Pengaruh Budaya Belajar terhadap Self-Efficacy Siswa Cerdas Istimewa di Sekolah Menengah Atas. Edudikara: Jurnal Pendidikan dan Pembelajaran, 6(3), 244-254.

lulusannya ke universitas terbaik di tingkat nasional maupun internasional dan merupakan sekolah yang menyelenggarakan layanan dua tahun, yakni program percepatan belajar bagi siswa cerdas istimewa melalui Sistem Kredit Semester (SKS). Budaya yang diterapkan di SMAN 78 Jakarta menekankan pada Penguatan Pendidikan Karakter (PPK) dengan pembiasaan sikap dan perilaku positif di sekolah untuk membangun jati diri peserta didik sesuai dengan nilai, norma, dan etika melalui pengembangan kultur sekolah dalam bentuk budaya religius, budaya berkarakter, budaya berprestasi, dan budaya mencintai lingkungan. Budaya tersebut menjadi cerminan terbentuknya budaya belajar yang baik pada siswa cerdas istimewa.

Permasalah yang terjadi adalah belum maksimalnya layanan individual yang diberikan guru kepada siswa cerdas istimewa dalam kelas yang heterogen, guru kesulitan membuat modul pembelajaran bagi siswa cerdas istimewa, rendahnya upaya sekolah dalam mensiasati pengembangan diri siswa cerdas istimewa dari segi sosial emosional, tingginya tekanan berprestasi yang diberikan orang tua, guru, dan sekolah terhadap siswa cerdas istimewa.

Masalah lain yang terjadi yakni belum seluruhnya siswa cerdas istimewa menerapkan budaya belajar secara baik. Ini menyebabkan adanya siswa cerdas istimewa yang tidak mampu beradaptasi dalam layanan dua tahun, kurang kepercayaan diri, adanya keraguan terhadap diri sendiri, kecemasan diri yang berlebihan, merasa stress dan tertekan, rasa takut tidak memenuhi ekspektasi, dan merasa terpuruk ketika menghadapi kegagalan, yang mengindikasikan bahwa masih terdapat siswa cerdas istimewa yang memiliki self-efficacy rendah.

Dengan demikian diduga terdapat pengaruh antara budaya belajar terhadap self-efficacy siswa cerdas istimewa. Tujuan penelitian ini adalah untuk mengumpulkan data empiris tentang pengaruh budaya belajar terhadap self-efficacy siswa cerdas istimewa. Penelitian ini diharapkan mampu mendorong siswa cerdas istimewa, guru, orang tua, maupun sekolah agar memaksimalkan peran dalam membentuk budaya belajar yang baik bagi siswa cerdas istimewa sehingga self-efficacy yang dimiliki dapat meningkat dan mereka lebih yakin dengan kemampuannya dalam meraih hasil belajar yang optimal serta mengatasi tantangan dan permasalahan belajar yang ada.

\section{METODE PENELITIAN}

Penelitian ini menggunakan metode kuantitatif deskriptif. Pemilihan metode ini didasarkan atas kebutuhan untuk menganalisis data-data yang bersifat kuantitatif berdasarkan prosedur statistik sehingga dapat ditarik pengertian dan maknanya. Lokasi penelitian ini dilaksanakan di SMAN 78 Jakarta yang terletak di Komp. Pajak Kemanggisan, Jakarta Barat.

Jumlah populasi yang akan digunakan yaitu 47 siswa cerdas istimewa. Peneliti memilih jenis teknik Simple Random Sampling dengan mengambil anggota sampel secara acak tanpa memperhatikan strata yang ada dalam populasi. Dari total 47 siswa, peneliti menentukan sampel dengan menggunakan tabel penentuan jumlah sampel yang dikembangkan oleh Isaac \& Michael yaitu menghitung sampel dengan taraf kesalahan $5 \%$ sehingga diperoleh sampel sebanyak 42 siswa cerdas istimewa yang akan digunakan pada penelitian.

Data dikumpulkan menggunakan angket, wawancara, dan studi dokumentasi. Angket disebar kepada 42 siswa cerdas istimewa dengan menggunakan bentuk pilihan skor skala likert yakni 4 alternatif jawaban, sedangkan wawancara dan studi dokumentasi hanya sebagai teknik pelengkap dalam pengumpulan data. Untuk membantu perhitungan, peneliti menggunakan IBM SPSS Statistics versi 22. Dari hasil uji validitas masing-masing variabel, butir item yang tidak valid kemudian didrop dan butir item yang valid akan digunakan untuk uji penelitian.

Hasil uji reliabilitas instrumen angket Budaya Belajar didapatkan Cronbach's Alpha 0,980 > 0,6 , yang artinya instrumen budaya belajar (variabel X) dapat dikatakan reliabel. Sedangkan hasil uji reliabilitas instrumen angket self-efficacy didapatkan Cronbach's Alpha 0,982 > 0,6, yang artinya instrumen self-efficacy siswa cerdas istimewa (variabel Y) reliabel. 
Aprilia. A. (2021). Pengaruh Budaya Belajar terhadap Self-Efficacy Siswa Cerdas Istimewa di Sekolah Menengah Atas. Edudikara: Jurnal Pendidikan dan Pembelajaran, 6(3), 244-254.

Teknik analisis data yang digunakan yaitu analisis deskriptif untuk menganalisis data dengan cara mendeskripsikan data-data yang telah berhasil terkumpul dari tiap variabel yang diteliti sehingga lebih mudah dipahami. Kemudian dilakukan uji prasyarat, yakni uji normalitas menggunakan kolmogorov-smirnov dan uji linearitas. Selanjutnya dilakukan uji hipotesis dengan uji korelasi, uji regresi linear sederhana, dan uji koefisien determinasi.

Uji korelasi yang digunakan yakni Korelasi Product Moment atau Pearson Correlation untuk mengetahui hubungan antara dua variabel, yang mengukur seberapa kuat hubungannya, arah hubungannya positif atau negatif, dan untuk mengetahui apakah hubungannya signifikan atau tidak (Duwi Priyatno, 2010). Untuk memprediksi bagaimana pengaruh variabel independen terhadap variabel dependen setelah diketahui ada hubungan antara variabel tersebut maka dianalisis dengan regresi (Sugiyono, 2018). Analisis regresi adalah analisis lanjutan dari korelasi. Analisis regresi linear sederhana digunakan untuk menguji sejauh mana pengaruh antara variabel $X$ terhadap variabel $Y$, apakah berpengaruh positif atau negatif, dan juga untuk memprediksi nilai variabel apakah mengalami kenaikan atau penurunan.

Kemudian dilakukan uji koefisien determinasi untuk menafsirkan skor Pearson Correlation dengan mengkuadratkan skor tersebut, sehingga diketahui berapa besar kontrubusi variabel $\mathrm{X}$ terhadap variabel Y jika dikalikan dengan $100 \%$.

\section{HASIL DAN PEMBAHASAN}

\section{Analisis Deskriptif}

Variabel dalam penelitian ini yaitu variabel X (Budaya Belajar) dan variabel Y (Self-Efficacy Siswa Cerdas Istimewa). Penelitian ini menggunakan teknik pengumpulan data berupa angket. Angket penelitian disebarkan kepada 42 siswa cerdas istimewa, terdiri dari 48 butir soal pada variabel $\mathrm{X}$ dan 42 butir soal pada variabel $\mathrm{Y}$.

\section{Data Variabel X (Budaya Belajar)}

Berdasarkan perhitungan, dapat diketahui bahwa nilai rata-rata (mean) dari variabel $\mathrm{X}$ (Budaya Belajar) adalah 148,02, nilai tengah (median) adalah 150,00, ada beberapa nilai yang paling sering muncul (modus) yakni 134, 143, 154, 161, nilai standar deviasi 14,129, nilai minimum 107, dan nilai maximum 172, sehingga diperoleh pengelompokkan tabel distribusi frekuensi sebagai berikut.

Tabel 2 Distribusi Frekuensi Variabel X

\begin{tabular}{|c|c|c|c|c|c|}
\hline \multicolumn{6}{|c|}{ IntervalX } \\
\hline & & Frequency & Percent & Valid Percent & Cumulative Percent \\
\hline \multirow[t]{7}{*}{ Valid } & $107-117$ & 2 & 4,8 & 4,8 & 4,8 \\
\hline & $118-128$ & 1 & 2,4 & 2,4 & 7,1 \\
\hline & 129-139 & 8 & 19,0 & 19,0 & 26,2 \\
\hline & $140-150$ & 11 & 26,2 & 26,2 & 52,4 \\
\hline & $151-161$ & 13 & 31,0 & 31,0 & 83,3 \\
\hline & $162-172$ & 7 & 16,7 & 16,7 & 100,0 \\
\hline & Total & 42 & 100,0 & 100,0 & \\
\hline
\end{tabular}

Sumber : Hasil olah data penelitian SPSS ver.22, 2021.

Selanjutnya untuk menentukan tingkat kecenderungan atau tinggi rendahnya variabel $X$ (Budaya Belajar) dengan menggunakan nilai rata-rata (mean) dan standar deviasi dengan bantuan SPSS diperoleh hasil berikut. 
Aprilia. A. (2021). Pengaruh Budaya Belajar terhadap Self-Efficacy Siswa Cerdas Istimewa di Sekolah Menengah Atas. Edudikara: Jurnal Pendidikan dan Pembelajaran, 6(3), 244-254.

Tabel 3. Tingkat Kecenderungan Data Variabel $X$

\begin{tabular}{|c|c|c|c|c|c|}
\hline \multicolumn{6}{|c|}{ Tingkat Kecenderungan Data Variabel X } \\
\hline & & Frequency & Percent & Valid Percent & Cumulative Percent \\
\hline \multirow[t]{4}{*}{ Valid } & Rendah & 3 & 7,1 & 7,1 & 7,1 \\
\hline & Sedang & 32 & 76,2 & 76,2 & 83,3 \\
\hline & Tinggi & 7 & 16,7 & 16,7 & 100,0 \\
\hline & Total & 42 & 100,0 & 100,0 & \\
\hline
\end{tabular}

Sumber : Hasil olah data penelitian SPSS ver.22, 2021.

Berdasarkan tabel di atas dapat diketahui bahwa perolehan skor variabel X (Budaya Belajar) yang termasuk ke dalam kategori rendah sebanyak 3 orang $(7,1 \%)$, kategori sedang 32 orang $(76,2 \%)$, dan kategori tinggi 7 orang $(16,7 \%)$. Berdasarkan perolehan skor tersebut dapat disimpulkan bahwa budaya belajar siswa cerdas istimewa di SMAN 78 Jakarta berada pada kategori sedang.

\section{Data Variabel Y (Self-Efficacy Siswa Cerdas Istimewa)}

Data self-efficacy siswa cerdas istimewa diperoleh dari hasil angket yang disebarkan kepada 42 siswa cerdas istimewa pada penelitian ini. Peneliti menggunakan IBM SPSS Statistics versi 22 untuk membantu perhitungan, dengan hasil sebagai berikut. Berdasarkan perhitungan, dapat diketahui bahwa nilai rata-rata (mean) dari variabel Y (Self-Efficacy Siswa Cerdas Istimewa) adalah 126,36, nilai tengah (median) adalah 126,50 , ada beberapa nilai yang paling sering muncul (modus) yakni 122, 126, 127, 132, 135, nilai standar deviasi 14,417, nilai minimum 89, dan nilai maksimum 161, sehingga diperoleh pengelompokkan tabel distribusi frekuensi sebagai berikut.

Tabel 5 Distribusi Frekuensi Variabel Y

\begin{tabular}{|c|c|c|c|c|c|}
\hline \multicolumn{6}{|c|}{ IntervalY } \\
\hline & & Frequency & Percent & Valid Percent & Cumulative Percent \\
\hline \multirow{8}{*}{ Valid } & $89-99$ & 2 & 4,8 & 4,8 & 4,8 \\
\hline & $100-110$ & 3 & 7,1 & 7,1 & 11,9 \\
\hline & $111-121$ & 9 & 21,4 & 21,4 & 33,3 \\
\hline & $122-132$ & 16 & 38,1 & 38,1 & 71,4 \\
\hline & $133-143$ & 8 & 19,0 & 19,0 & 90,5 \\
\hline & $144-154$ & 2 & 4,8 & 4,8 & 95,2 \\
\hline & $155-165$ & 2 & 4,8 & 4,8 & 100,0 \\
\hline & Total & 42 & 100,0 & 100,0 & \\
\hline
\end{tabular}

Sumber : Hasil olah data penelitian SPSS ver.22, 2021

Selanjutnya untuk menentukan tingkat kecenderungan atau tinggi rendahnya variabel $X$ (Budaya Belajar) dengan menggunakan nilai rata-rata (mean) dan standar deviasi dengan bantuan SPSS diperoleh hasil berikut.

Tabel 6 Tingkat Kecenderungan Data Variabel Y

\begin{tabular}{llllll}
\hline \multicolumn{5}{c}{ Tingkat Kecenderungan Data Variabel Y } \\
\hline & & Frequency & Percent & Valid Percent & Cumulative Percent \\
\hline Valid & Rendah & 5 & 11,9 & 11,9 & 11,9 \\
& Sedang & 32 & 76,2 & 76,2 & 88,1 \\
& Tinggi & 5 & 11,9 & 11,9 & 100,0 \\
& Total & 42 & 100,0 & 100,0 & \\
\hline
\end{tabular}

Sumber : Hasil olah data penelitian SPSS ver.22, 2021.

Berdasarkan tabel di atas dapat diketahui bahwa perolehan skor variabel Y (Self-Efficacy Siswa Cerdas Istimewa) yang termasuk ke dalam kategori rendah sebanyak 5 orang $(11,9 \%)$, 
Aprilia. A. (2021). Pengaruh Budaya Belajar terhadap Self-Efficacy Siswa Cerdas Istimewa di Sekolah Menengah Atas. Edudikara: Jurnal Pendidikan dan Pembelajaran, 6(3), 244-254.

kategori sedang 32 orang $(76,2 \%)$, dan kategori tinggi 5 orang (11,9\%). Berdasarkan perolehan skor tersebut dapat disimpulkan bahwa self-efficacy siswa cerdas Istimewa berada pada kategori sedang.

\section{Uji Prasyarat}

Berdasarkan hasil uji normalitas diperoleh data pada variabel X (Budaya Belajar) dan variabel Y (Self-Efficacy Siswa Cerdas Istimewa) memiliki nilai signifikansi Kolmogorov-Smirnov yang baik yakni sebesar 0,200 . Sehingga dapat diambil kesimpulan bahwa data berdistribusi normal karena nilai signifikansi Kolmogorov-Smirnov >0,05.

Hasil uji linearitas menunjukkan nilai signifikansi pada Deviation from Linearity sebesar 0,140, maka dapat diartikan bahwa terdapat hubungan yang linear antara variabel $X$ (Budaya Belajar) dan variabel $Y$ (Self-Efficacy Siswa Cerdas Istimewa) karena Deviation from Linearity $(0,140)>$ taraf signifikansi $(0,05)$, sehingga asumsi linearitas terpenuhi.

\section{Uji Hipotesis}

Hasil uji korelasi (uji-r) menunjukkan bahwa rhitung bernilai positif sebesar 0,829 dan rtabel sebesar 0,304 dengan signifikansi sebesar 0,000. Dengan hasil pengujian rhitung $>$ rtabel dan signifikansi $<0,05$, maka terdapat hubungan yang signifikan antara budaya belajar terhadap self-efficacy siswa cerdas istimewa dalam tingkatan sangat kuat dan searah. Artinya, semakin baik penerapan budaya belajar maka akan semakin tinggi self-efficacy yang dimiliki siswa cerdas istimewa. Begitupun sebaliknya.

Untuk mengetahui bagaimana pengaruh variabel $X$ (Budaya Belajar) terhadap variabel $Y$ (Self-Efficacy Siswa Cerdas Istimewa) maka dilakukan uji regresi linear sederhana. Dari hasil penelitian, diperoleh nilai koefisien regresi sebesar 0,845 yang menunjukkan koefisien regresi bernilai positif, maka dapat dikatakan bahwa budaya belajar $(\mathrm{X})$ berpengaruh positif terhadap self-efficacy siswa cerdas istimewa $(Y)$. Sehingga persamaan regresinya adalah $Y^{\prime}=1,217+$ $0,845 \mathrm{X}$.

Selanjutnya berdasarkan uji determinasi ditemukan nilai koefisien determinasi (R Square) sebesar 0,686 (68,6\%). Angka tersebut mengandung arti bahwa variabel budaya belajar memiliki pengaruh terhadap variabel self-efficacy siswa cerdas istimewa sebesar $68,6 \%$, sementara sisanya $31,4 \%$ dipengaruhi oleh faktor lain yang tidak diteliti.

Berdasarkan analisis yang telah dilakukan, dapat disimpulkan bahwa budaya belajar berpengaruh sebesar $68,6 \%$ terhadap self-efficacy siswa cerdas istimewa di SMAN 78 Jakarta. Hasil wawancara dengan Wakasek Kesiswaan SMAN 78 Jakarta menyatakan memang sedikit banyaknya ada pengaruh antara budaya belajar dengan self-efficacy siswa cerdas istimewa. Makin baik kebiasaan belajar siswa maka ia akan semakin yakin dengan kemampuannya untuk menyelesaikan layanan dua tahun. Dalam mengikuti layanan dua tahun, siswa cerdas istimewa tidak bisa hanya mengandalkan IQ tanpa memiliki kebiasaan belajar yang baik, sebab ia akan terpontang-panting dalam mengikuti layanan dua tahun dan merugikan dirinya sendiri.

Hal serupa juga disampaikan oleh guru Bimbingan dan Konseling SMAN 78 Jakarta, beliau mengatakan bahwa self-efficacy atau keyakinan diri yang dimiliki siswa cerdas istimewa memang berawal dari budaya atau kebiasaan belajar individu tersebut. Jika ia memiliki kebiasaan belajar yang baik, itu yang akan membuatnya semakin percaya diri. Kebiasaan belajar yang baik sangat penting sekali dimiliki siswa cerdas istimewa, karena modal utamanya hanya itu. Jika siswa tersebut belajarnya tidak rutin, belajarnya sesuai mood, belajar jika hanya ada ulangan, tentu saja tidak bisa. Siswa tersebut tidak akan bisa mengejar modulnya, yang ada ia akan stress dan tidak mampu bertahan. Jadi, kebiasaan belajar yang baik adalah modal utama agar siswa cerdas istimewa merasa yakin dengan kemampuan yang dimilikinya. Senada dengan hal itu, Pak Harry selaku Wakasek Bidang Kurikulum SMAN 78 Jakarta juga mengatakan bahwa rata-rata siswa cerdas istimewa yang bertahan dan berhasil menyelesaikan layanan dan 
Aprilia. A. (2021). Pengaruh Budaya Belajar terhadap Self-Efficacy Siswa Cerdas Istimewa di Sekolah Menengah Atas. Edudikara: Jurnal Pendidikan dan Pembelajaran, 6(3), 244-254.

tahun serta mencapai tujuannya adalah mereka yang memang punya kebiasaan belajar baik, tangguh dalam belajar, ulet, dan berkomitmen.

Sebagaimana yang dikemukakan oleh Bandura (Tim Psychologimania) bahwa salah satu faktor yang mempengaruhi self efficacy adalah faktor budaya. Budaya yang diperoleh melalui proses pembelajaran oleh seseorang atau sekelompok orang dalam lingkungannya dapat berkembang menjadi budaya belajar. Maka dapat diartikan bahwa budaya belajar yang dimiliki oleh siswa cerdas istimewa dapat menjadi salah satu faktor yang mempengaruhi self-efficacy, hal ini diperkuat oleh hasil penelitian yang memperlihatkan budaya belajar berpengaruh sebesar $68,6 \%$ terhadap self-efficacy siswa cerdas istimewa di SMAN 78 Jakarta.

Dengan demikian, berdasarkan hasil perhitungan data dan wawancara yang diperoleh dari lapangan terlihat adanya pengaruh yang positif sebesar $68,6 \%$ variabel budaya belajar terhadap self-efficacy siswa cerdas istimewa di SMAN 78 Jakarta.

\section{SIMPULAN DAN SARAN}

Berdasarkan hasil penelitian diperoleh bahwa terdapat pengaruh yang positif antara budaya belajar terhadap self-efficacy siswa cerdas istimewa di SMAN 78 Jakarta. Artinya, semakin baik penerapan budaya belajar maka akan semakin tinggi self-efficacy yang dimiliki siswa cerdas istimewa. Budaya belajar memiliki pengaruh sebesar $68,6 \%$, terhadap self-efficacy siswa cerdas istimewa sementara sisanya $31,4 \%$ dipengaruhi oleh faktor lain yang tidak diteliti.

Melihat besarnya pengaruh budaya belajar terhadap self-efficacy siswa cerdas istimewa, siswa cerdas istimewa diharapkan agar menerapkan budaya belajar yang baik sehingga tidak akan mengalami stress yang berlebihan dan mampu menghadapi tekanan-tekanan dengan baik dalam mengikuti layanan percepatan belajar. Dengan begitu maka akan meningkatkan self-efficacy atau keyakinan diri terhadap kemampuan dan potensi yang dimilikinya dan menjadikan siswa tidak mudah untuk menyerah.

Selain itu, guru ataupun orang tua diharapkan dapat membentuk budaya belajar yang baik bagi siswa cerdas istimewa sehingga self-efficacy yang dimiliki dapat meningkat dan mereka mampu meraih hasil belajar yang optimal. Bagi sekolah yang menyelenggarakan layanan percepatan belajar diharapkan agar memperkuat penerapan budaya yang positif di lingkungan sekolah dalam upaya meningkatkan kualitas belajar siswanya. Sebab untuk membangun budaya belajar siswa harus diawali dari membangun budaya organisasi (sekolah) yang bersangkutan.

Dengan memiliki budaya atau kebiasaan belajar yang baik, siswa cerdas istimewa akan mempersiapkan dirinya sebaik mungkin untuk mengatasi persoalan belajar yang ada sehingga akan merasa yakin terhadap kemampuan dan potensinya dan meningkatkan self-efficacy yang dimilikinya. Self-efficacy sangat penting dimiliki siswa dalam mengerjakan tugas belajarnya dan menghadapi situasi belajar yang ada. Self-efficacy merupakan salah satu dasar bagi siswa untuk dapat membantu atau mendukung dirinya dalam menghadapi permasalahan.

Siswa cerdas istimewa yang memiliki self-efficacy yang tinggi akan mampu secara mandiri untuk menghadapi permasalahan yang ada, termasuk dalam hal menyelesaikan tugas-tugas dengan kemampuan yang dimilikinya. Siswa tidak akan mengalami stress yang berlebihan ketika telah mampu mengukur sejauh mana kemampuan dirinya dan dapat mengeluarkan potensi yang dimiliki dengan optimal, sehingga siswa akan mampu menghadapi tekanantekanan dengan baik karena memiliki komitmen dan kesadaran penuh terhadap tanggung jawabnya sebagai subjek belajar. 
Aprilia. A. (2021). Pengaruh Budaya Belajar terhadap Self-Efficacy Siswa Cerdas Istimewa di Sekolah Menengah Atas. Edudikara: Jurnal Pendidikan dan Pembelajaran, 6(3), 244-254.

\section{REFERENSI}

Alwisol. 2019. Psikologi Kepribadian Edisi Revisi. Malang: UMM Press.

Ansori, Miksan. 2015. Panduan Analisis Manual Penelitian Kuantitatif. Ngawi: Sekolah Tinggi IImu Tarbiyah Muhammadiyah.

Arif, Saiful. 2011. "Budaya Belajar Siswa Pada Sekolah Unggul di SMA Negeri 1 Pamekasan”. Jurnal Nuansa. 8(2): 190.

Arikunto, Suharsimi. 2013. Prosedur Penelitian Suatu Pendekatan Praktik. Jakarta: Rineka Cipta.

Aziz, Mursal. 2017. "Manajemen Kurikulum dalam Pengembangan Budaya Belajar di Madrasah Aliyah Mu'Allimin Unia Medan", Jurnal Pendidikan ITTIHAD, 1(2): 203-304.

Baharuddin. 2016. Pendidikan \& Psikologi Perkembangan. Jogjakarta: Ar Ruzz Media.

Eva, Nur dan Moh. Bisri. 2018. Kesejahteraan Psikologis Siswa Cerdas Istimewa. Malang: Universitas Negeri Malang.

Ghufron, M. dan Rini Risnawita. 2012. Teori-teori Psikologi. Jogjakarta: Ar-Ruzz Media.

Handayani, Febrina dan Desi Nurwidawati. 2013. "Hubungan Self Efficacy Dengan Prestasi Belajar Siswa Akselerasi". Jurnal Penelitian Psikologi, 1(2).

Hery Yoenanto, Nono. 2010. "Hubungan antara Self-Regulated Learning dengan Self-Efficacy pada Siswa Akselerasi Sekolah Menengah Pertama di Jawa Timur". INSAN, 12(2): 89.

Kartika Dewi, Warni. 2015. "Evaluasi Pelaksanaan Program Cerdas Istimewa (CI) Akselerasi di SMA Negeri 5 Yogyakarta". Jurnal Manajemen Pendidikan.

Koentjaraningrat. 2009. Pengantar Ilmu Antropologi. Jakarta: Rineka Cipta.

Maria, Julia dan Endang Widyorini. 2014. Deteksi dan Penanganan Anak Cerdas Istimewa (Anak Gifted) Melalui Pola Alamiah Tumbuh Kembangnya. Jakarta: Prenada Media Group.

Maya Sari, Wanda. "Perbandingan Distribusi Frekuensi Antara Metode Sturges dan Scott". Jurnal Saintia Matematika, (20)20: 9.

Merdekawaty, Ana dan Fatmawati. 2019. “Pengaruh Kemandirian Belajar Dan Efikasi Diri Terhadap Pemahaman Akuntansi Siswa". Jurnal IImiah Pendidikan Ekonomi Fakultas Keguruan dan IImu Pendidikan, 7(2): 97.

Mukhid, Abd. 2009. "Self-Efficacy: Perspektif Teori Kognitif Sosial dan Implikasinya Terhadap Pendidikan". Tadrîs, 4(1): 108.

Nurhastuti. 2018. "Tes Potensi Anak Cerdas Istimewa dan Berbakat Istimewa”. Sketsa Pendidikan Jurnal Pendidikan dan Kebudayaan, 3(I): 12.

Nugraha, Hafiz dan Ambiyar. 2018. "Pengaruh Budaya Belajar Terhadap Hasil Belajar Keterampilan Komputer dan Pengelolaan Informasi Siswa Sekolah Menengah Kejuruan Muhammadiyah 1 Padang". Jurnal Inovasi Vokasional dan Teknologi, 18(2): 49.

Permana, Hara, Farida Harahap, dan Budi Astuti. 2016. "Hubungan Antara Efikasi Diri dengan Kecemasan dalam Menghadapi Ujian pada Siswa Kelas IX di MTs Al Hikmah Brebes”. Jurnal Hisbah, 13(1): 5859

Priyatno, Duwi. 2010. Teknik Mudah dan Cepat Melakukan Analisis Data dengan SPSS. Yogyakarta: Gava Media.

Rosadi, Nanang dan Iwan Wahyu Widayat. 2013. “Hubungan antara Perfeksionisme dengan Depresi pada Siswa Cerdas Istimewa di Kelas Akselerasi". Jurnal Psikologi Pendidikan dan Perkembangan, $2(1): 2$

Rusyan, Tabrani. 2007. Budaya Belajar yang Baik. Jakarta: PT Panca Anugerah Sakti.

Saipul Hidayat, Deden dan Wawan Gunawan. 2013. Mengembangkan Pendidikan Bagi Peserta Didik Cerdas Istimewa dan Bakat Istimewa CIBI. Jakarta: PT Luxima Metro Media.

Siregar, Syofian. 2011. Statistika Deskriptif untuk Penelitian: Dilengkapi Perhitungan Manual dan Aplikasi SPSS. Jakarta: PT RajaGrafindo Persada.

Slameto. 2018. Belajar dan Faktor-faktor yang Mempengaruhinya. Jakarta: Rineka Cipta.

SMAN 78 Jakarta, sman78-jkt.sch.id.

Soekanto, Soerjono. 2013. Sosiologi Suatu Pengantar. Jakarta: PT.RajaGrafindo Persada.

Sufirmansyah. 2015. "Pengaruh Efikasi Diri Terhadap Prestasi Belajar Mahasiswa Pascasarjana Prodi PAI STAIN Kediri dengan Motivasi Sebagai Variabel Intervening", Jurnal Didaktika Religia, 3(2): 143.

Sugiarti, Rini. 2019. Karakteristik Siswa Cerdas Istimewa. Banyumas: CV. Pena Persada.

Sugiyono. 2016. Metode Penelitian Kuantitatif, Kualitatif, dan R\&D. Bandung: Alfabeta. 
Aprilia. A. (2021). Pengaruh Budaya Belajar terhadap Self-Efficacy Siswa Cerdas Istimewa di Sekolah Menengah Atas. Edudikara: Jurnal Pendidikan dan Pembelajaran, 6(3), 244-254.

Susanti, Tri. 2015. "Profil Empati Siswa Cerdas Istimewa di SMA Negeri Kota Yogyakarta". Jurnal Konseling Komperhensif, 2(1): 25.

Suseno, Miftahun Ni'mah. 2009. "Pengaruh Pelatihan Komunikasi Interpersonal Terhadap Efikasi Diri sebagai Pelatih pada Mahasiswa". Jurnal Intervensi Psikologi. 1(1): 95.

Susetyo, Budi. 2010. Statistika untuk Analisis Data Penelitian. Bandung: PT Refika Aditama.

Tim Pengembang IImu Pendidikan FIP UPI. 2009. Ilmu dan Aplikasi Pendidikan Jilid 1. Bandung: PT. Imperial Bhakti Utama.

Tim Psychologimania, Faktor-faktor yang Mempengaruhi Self-Efficacy, https://www.psychologymania .com/2012/10/faktor-faktor-yang-mempengaruhi-self.html?m=1.

Tim Psychologymania, Faktor-Faktor yang Mempengaruhi Kebiasaan Belajar, https://www. psychologymania.com/2012/06/faktor-faktor-yang-mempengaruhi-13.html.

Winarto dan Lantip Diat P. 2017. "Strategi Pengembangan Budaya Pembelajaran di Sekolah". Jurnal Akuntabilitas Manajemen Pendidikan. 5(1): 114.

Wulandari, Silvia dan Mira Aliza. 2014. "Efikasi Diri dan Stress Akademik pada Siswa SMA Program Akselerasi”. Psikologika, 19(2): 152. 